\title{
Effect of preoperative vitamin D deficiency on postoperative hypocalcemia after thyroid surgery
}

\author{
Mayank Tripathi ${ }^{1 *}$, Rajender Kumar Karwasra ${ }^{1,2}$ and Sanjeev Parshad ${ }^{2}$
}

\begin{abstract}
Background: Transient post thyroidectomy hypocalcemia occurs in up to 30\% of patients. We evaluated the effect of vitamin D deficiency on post thyroidectomy hypocalcaemia.

Methods: This is a prospective study which was conducted from November 2010 to January 2013 and a total of 35 patients were included and data was analyzed regarding the relation between preoperative vitamin D3 levels and occurrence of post- thyroidectomy hypocalcemia. Patients were divided into two groups dependent upon the preoperative serum vitamin D level: group 1 with vitamin D levels $<20 \mathrm{ng} / \mathrm{ml}$ and group 2 with serum vitamin D levels $\geq 20 \mathrm{ng} / \mathrm{ml}$. Hypocalcemia was defined as a postoperative calcium level $<8.5 \mathrm{mg} / \mathrm{dl}$.
\end{abstract}

Results: There was a difference in postoperative hypocalcemia between the two vitamin D groups. In patients with serum vitamin $D \leq 20 \mathrm{ng} / \mathrm{ml}$ mean pre-operative and post-operative serum calcium levels were $9.3 \pm 0.5$ and $8.4 \pm 0.58 \mathrm{~g} \mathrm{dl}(\mathrm{p}<.001)$ whereas in patients with serum vitamin D levels $>20 \mathrm{ng} / \mathrm{ml}$ mean pre-operative and post-operative serum calcium were $9.52 \pm 0.64$ and $8.9 \pm 0.5(p=n s)$.

Conclusions: Pre-operative serum vitamin D levels have got positive correlation with serum calcium levels in early post-operative period. Patients with serum vitamin D levels $<20 \mathrm{ng} / \mathrm{ml}$ are highly likely to develop early post-operative hypocalcaemia and the difference between pre-operative and post-operative serum calcium levels in vitamin $\mathrm{D}$ deficient patients was significant $(p<0.001)$.

\section{Introduction}

Hypocalcemia is a well-known complication and concern following thyroid surgery. Although in most cases it is only temporary, post-thyroidectomy hypocalcemia can lead to an increased cost by prolonging the length of stay and increasing the need for expensive medications, frequent biochemical tests and multiple outpatient visits [1]. The incidence of transient hypocalcemia has been estimated to occur between $3 \%$ to $30 \%$ of cases even after preservation of one or more parathyroids [2]. Permanent hypocalcaemia, although much less frequent, still occurs, with an incidence of around 2-4\% reported in the literature [3]. Only a small percentage of patients with biochemical hypocalcemia develop symptoms, which most commonly manifest as mild perioral or distal acral paresthesias. Less frequently, patients may develop more severe symptoms such as carpopedal spasm, tetany,

\footnotetext{
* Correspondence: drmayanktripathi1@gmail.com

'Department of Surgical Oncology, Pt.B.D.Sharma PGIMS and UHS, Rohtak, Haryana 124001, India

Full list of author information is available at the end of the article
}

laryngospasm or in rare cases, cardiac arrhythmias [2]. Although a common occurrence, causes and mechanisms of post thyroidectomy hypocalcemia are unclear. It was first attributed to injury, devascularization, or inadvertent removal of the parathyroid glands. However, the high frequency of post thyroidectomy hypocalcemia even after lobectomy led some authors to challenge the traditional explanation, as it seemed unlikely that the parathyroid glands could be injured or damaged in almost all thyroidectomies [4].

Many factors are postulated to increase the risk of hypocalcemia, including old age Graves' disease, surgical techniques, concurrent neck dissection, large surgical volumes, and the surgeon's experience, which have all been shown to increase the risk of hypocalcemia [4-6]. Recently few studies have suggested the role of 25hydroxycholecalciferol (vitamin D3) deficiency in the occurrence of hypocalcaemia after thyroidectomy [4]. Intuitively, prescribing vitamin D and calcium prophylactically after thyroidectomy has shown to reduce the incidence of hypocalcaemia $[7,8]$. It has also been suggested that the 
combination of calcitriol and hydrochlorothiazide after thyroidectomy may reduce the risk of hypocalcemia [8]. The health implications of vitamin D deficiency have become a key area of research. Vitamin D deficiency has been associated with bone disease, malignancy, lipid metabolism defects, diabetes, and heart disease. Reference ranges for normal vitamin $\mathrm{D}$ levels and the levels at which pathological correlation can be made are not well established and vary from institution to institution. Demonstrating a correlation between preoperative vitamin D levels and occurrence of post thyroidectomy may reveal an easily correctable factor.

Following ethical approval this prospective study was conducted at a tertiary care hospital on patients who presented with goiter. Patients with evidence of hyperthyroidism, concomitant parathyroid disease, metabolic bone disease and patients with previous thyroid or neck surgery were excluded from the study.

\section{Measurements}

Pre-operative thyroid function tests were performed in all the patients and only euthyroid patients were taken up for surgery. Total Serum calcium, PTH, 25-OHD, and albumin levels were determined the day before surgery. Serum calcium $\left(\mathrm{ca}^{2+}\right)$ and albumin levels were determined by an auto analyzer. Serum 25-OHD and PTH (parathormone) levels were determined by ELISA using commercially available kits. Thyroidectomies were performed by consultant surgeons, during surgery recurrent laryngeal nerves were preserved and an attempt was made to identify all parathyroid glands and to preserve their blood supply by meticulous dissection. In case ischemic changes were noted parathyroids were reimplanted in the ipsilateral sternocleidomastoid muscle. Serum $\mathrm{Ca}^{2+}$ and PTH levels were measured 12 hours postoperatively, and measurements of serum $\mathrm{ca}^{2+}$ levels were repeated 24 hours postoperatively. Repeated measurement of serum $\mathrm{ca}^{2+}$ was performed at 1 week, 2 week, 1 month, 2 months and 3 months in post-operative period. Albumin corrected calcium was calculated by adding $1 \mathrm{mg} / \mathrm{dl}$ to the serum calcium level for every $1 \mathrm{gm} / \mathrm{dl}$ by which serum albumin level is below $4 \mathrm{gm} / \mathrm{dl}$. Any sign of hypocalcemia in the form of facial paresthesia, positive Chvostek or Trousseau signs, and muscular spasm were noted in the pre-operative as well as in the immediate post-operative period and on follow-up. Reference ranges of biochemical parameters are as follows: 8.5 to 10.5 $\mathrm{mg} / \mathrm{dL}$ for serum $\mathrm{ca}^{2+} ; 3.5$ to $5.0 \mathrm{~g} / \mathrm{dL}$ for serum albumin, 20-100 ng/mL for serum 25-OHD (vitamin D) and 10 to $65 \mathrm{pg} / \mathrm{mL}$ for serum PTH. Hypocalcemia was defined as serum $\mathrm{ca}^{2+}$ levels less than normal reference range in our institute i.e. $<8.5 \mathrm{mg} / \mathrm{dl}$. Transient post-operative hypocalcemia was defined as hypocalcemia occurring in first $48 \mathrm{hrs}$ after the surgery and patient was considered as having permanent hypocalcemia if clinical or biochemical evidence of hypocalcaemia were present at 3 month follow-up. Vitamin deficiency was defined as serum vitamin D levels $<20 \mathrm{ng} / \mathrm{ml}$. All of the patients who developed asymptomatic hypocalcemia were treated with oral calcium carbonate (3-6 g/d). Symptomatic hypocalcemia was treated with parenteral calcium gluconate and an oral calcitriol supplementation of 1.0 to $1.5 \mu \mathrm{g} / \mathrm{d}$. Patients were divided in two groups based on their serum vitamin D levels, group 1 consisted of patients with serum vitamin D levels $<20 \mathrm{ng} / \mathrm{ml}$ and in group 2 patients with serum vitamin D levels $\geq 20 \mathrm{ng} / \mathrm{ml}$ were included. Pattern of serum $\mathrm{ca}^{2+}$, serum PTH and thyroid diseases (malignant vs benign) were studied in these patients. All patients were followed up to 3 months following discharge and any evidence of symptomatic or biochemical hypocalcemia was recorded. Data was collected and was analysed using SPSS statistical software.

\section{Results}

The mean age for patients included in the study was $37.4 \pm 15.39$ years (range13-65 years) with male to female ratio of 1:6. Out of 35 patients included in our study $19(54.29 \%)$ patients underwent hemithyroidectomy and $16(45.7 \%)$ patients had total thyroidectomy (TT). The means $\pm \mathrm{SD}$ for pre-operative and post-operative serum albumin $[\mathrm{n}=35]$ were $4.79 \pm 0.88 \mathrm{~g} / \mathrm{dl}$ and $4.64 \pm$ $0.82 \mathrm{~g} / \mathrm{dl}$ respectively. Mean serum vitamin D level of the patients under study was $16.22 \pm 12.85 \mathrm{ng} / \mathrm{ml}$. Out of 35 patients, $24(68.5 \%)$ had serum vitamin D level $<20 \mathrm{ng} / \mathrm{ml}$ and 11(31.5\%) had serum vitamin D levels $\geq 20 \mathrm{ng} / \mathrm{ml}$. In control group of 30 apparently healthy individuals, mean serum vitamin D levels were $20.3 \pm 7.7 \mathrm{ng} / \mathrm{ml}$ ranging from 9-39 $\mathrm{ng} / \mathrm{ml}$. 16 individuals (53.3\%) were having serum vitamin $\mathrm{D}$ levels $\leq 20 \mathrm{ng} / \mathrm{ml}$ indicating a high prevalence of vitamin D deficiency in our population. Mean pre-op and post-op serum PTH levels $[n=35]$ were $24.4 \pm 10.2 \mathrm{pg} / \mathrm{ml}$ and $20 \pm 10 \mathrm{pg} / \mathrm{ml}$ respectively indicative of a $18 \%$ fall in post-operative period which was higher i.e. $35 \%$ in patients undergoing TT than in patients undergoing hemithyroidectomy who had a fall of $11 \%$. On applying Pearson Correlation Coefficients there was a significant positive correlation between postoperative serum PTH and postoperative serum $\mathrm{ca}^{2+}$ at 24 hrs. $(P=0.0113)$ but there was no significant correlation between pre-operative vitamin $\mathrm{D}$ and pre-operative PTH $(\mathrm{p}=0.4155)$ and post-operative PTH $(\mathrm{p}=0.1938)$.

The difference between pre-op and post-op PTH levels was statistically significant $(t=4.47$ and $p=0.001)$. In patients undergoing TT with or without modified radical neck dissection (MRND) the pre-op and post-op-PTH levels were $23.7 \pm 9.2$ and $15.3 \pm 7.9 \mathrm{pg} / \mathrm{ml}$ with a significant difference in pre-operative and post-operative levels $(t=5.08, \mathrm{p}=.0001)$ whereas in patients undergoing 
hemithyroidectomy mean pre-op and post-op parathormone levels were $25.11 \pm 11.1$ and $22.5 \pm 10.8(t=2 p=$ $0.062)$, this difference was not statistically significant. Mean pre-op $[\mathrm{n}=35]$ serum $\mathrm{ca}^{2+}$ was $9.3 \pm 0.54 \mathrm{mg} / \mathrm{dl}$ (normally distributed $\mathrm{P}<0.037$ ) and mean post-op serum $\mathrm{ca}^{2+}$ were $8.7 \pm 0.6 \mathrm{mg} / \mathrm{dL}$ at 12 hrs (normally distributed $\mathrm{P}<0.049$ ), $8.6 \pm 0.58$ at 24 hrs (not- normally distributed $\mathrm{P}>0.15), 8.7 \pm 0.43$ at 1 week and $8.9 \pm 0.31$ at 3 months. Difference between mean pre-op serum $\mathrm{ca}^{2+}$ and mean post-op serum $\mathrm{ca}^{2+}$ at 24 hrs was statistically significant $(\mathrm{t}=6.94$ and $\mathrm{p}<0.001)$. In patients with serum vitamin $\mathrm{D} \leq 20 \mathrm{ng} / \mathrm{ml}$ mean pre-operative and post-operative serum $\mathrm{ca}^{2+}$ levels were $9.3 \pm 0.5$ and $8.4 \pm 0.58 \mathrm{~g} \mathrm{dl}$ $(\mathrm{p}<.001)$ whereas in patients with serum vitamin $\mathrm{D}$ levels $>20 \mathrm{ng} / \mathrm{ml}$ mean pre-operative and post-operative serum $\mathrm{ca}^{2+}$ were $9.52 \pm 0.64$ and $8.9 \pm 0.5(\mathrm{p}=\mathrm{ns})$. In patients undergoing TT with or without MRND [n=16] mean pre-op serum $\mathrm{ca}^{2+}$ and mean post-op serum $\mathrm{ca}^{2+}$ (at $24 \mathrm{hr}$ ) were $9.5 \pm 0.4$ and $8.34 \pm 0.54$ with a statistically significant difference. In patients undergoing hemithyroidectomy mean pre-op serum $\mathrm{ca}^{2+}$ and post-op serum $\mathrm{ca}^{2+}$ (at 24 hrs.) were $9.25 \pm 0.6$ and $8.82 \pm 0.54$ with no statistically significant difference. Observations made in two groups i.e. group 1 (vitamin $\mathrm{D}<20 \mathrm{ng} / \mathrm{ml}$ ) and group 2(vitamin $D \geq 20 \mathrm{ng} / \mathrm{ml}$ ) are summarized in following Table 1 .

Out of 24 patients with serum vitamin D levels $<20$ $\mathrm{ng} / \mathrm{ml} \mathrm{11(46 \% )}$ developed post-operative hypocalcemia, it's worth noting here that overall 12 patients developed post-operative hypocalcemia in the patients under study $(\mathrm{n}=35)$, and $11(90 \%)$ of them were vitamin D deficient. In patients with serum vitamin D levels $\geq 20 \mathrm{ng} / \mathrm{ml}$ only one patient developed post-operative hypocalcemia who had TT.

\section{Evaluation of patients according to postoperative hypocalcemia}

Out of 35 patients included in the study no patient developed symptomatic hypocalcemia in first $12 \mathrm{hrs}$, however biochemical hypocalcemia was noted in $8(22.8 \%)$ patients. In first $24 \mathrm{hrs} 7$ patients (20\%) developed symptomatic hypocalcemia and $12(34.3 \%)$ patients developed biochemical hypocalcemia. This temporary hypocalcemia disappeared gradually and no patient was symptomatic on 7th POD, however biochemical hypocalcemia persisted in $5(14 \%)$ patients at one week POD. On follow-up after 3 months, no patient was having either symptomatic or biochemical hypocalcemia however 3(8.5\%) patients who underwent TT with neck dissection and one (2.8\%) who had TT were on oral calcium.

\section{Discussion}

Postoperative hypocalcemia is a major concern following thyroid surgery. When severe, it can lead to serious complications and requires intravenous therapy to alleviate the clinical symptoms. [2] Temporary hypocalcemia if untreated or undiagnosed, may lead to paraesthesia, tetany, and an increased duration of hospital stay with repeated blood tests and increase cost of thyroid surgery [1].

In our study [ $\mathrm{n}=35]$, during the first $24 \mathrm{hrs} 12(34.3 \%)$ patients developed biochemical hypocalcemia out of which 7 patients $(20 \%)$ were symptomatic; however 3 (8.5\%) patients who underwent TT with neck dissection and one $(2.8 \%)$ patient who had TT were on oral calcium carbonate on 3 month follow-up indicative of permanent hypoparathyroidism. This data is in concordance with the literature available on this issue [1,4,9-12].

\section{Surgical technique and occurrence of post-operative hypocalcemia}

Both Billroth and Kocher noticed occurrence of tetany following thyroid surgery [5]. In last two decades TT has become the procedure of choice for both malignant and benign thyroid diseases leading to a search for ways to reduce the incidence of hypocalcemia following thyroid surgery. One of the most important reasons is the technique of TT (extracapsular vs capsular) and extent of dissection (no nodal dissection vs nodal dissection). In our study, we performed TT only in malignant diseases of thyroid which was often combined with a neck dissection procedure; hence to achieve a better oncological clearance we adopted extracapsular technique. However in TT for benign diseases and in hemithyroidectomy procedure we adhered to capsular dissection. Patients who underwent extracapsular dissection are more likely to develop hypocalcemia as reported by Thomusch et al. [5] They performed bilateral thyroid surgery in 5846

Table 1 Summary of observations made in two groups i.e. group 1 (vitamin $\mathrm{D}<20 \mathrm{ng} / \mathrm{ml}$ ) and group 2 (vitamin $D \geq 20 \mathrm{ng} / \mathrm{ml}$ )

\begin{tabular}{lll}
\hline Parameters & Serum vitamin $\mathbf{D}<\mathbf{2 0} \mathbf{n g} / \mathbf{m l}(\mathbf{n}=\mathbf{2 4})$ & Serum vitamin $\mathbf{D} \geq \mathbf{2 0} \mathbf{n g} / \mathbf{m l}(\mathbf{n}=\mathbf{1 1})$ \\
\hline Mean pre-operative serum calcium $(\mathrm{mg} / \mathrm{d})$ & $9.3 \pm 0.5$ & $9.52 \pm 0.64$ \\
Mean post-operative serum calcium $(\mathrm{mg} / \mathrm{d})$ & $8.4 \pm 0.58$ & $8.9 \pm 0.5$ \\
No. of patients developing hypocalcaemia in post-operative period & 11 & 1 \\
Mean pre-operative serum PTH $(\mathrm{pg} / \mathrm{ml})$ & $25 \pm 11.4$ & $23.2 \pm 7.2$ \\
Mean post-operative serum PTH $(\mathrm{pg} / \mathrm{ml})$ & $19.8 \pm 11.5$ & $20.4 \pm 6.2$ \\
\% fall in PTH & $21 \%$ & $12 \%$ \\
\hline
\end{tabular}


patients for benign and malignant thyroid disease. They concluded that the extent of resection and surgical technique had a greater impact on the rates of permanent postoperative hypoparathyroidism than thyroid pathologic condition. In their study $\mathrm{TT}$, bilateral central ligation of the inferior thyroid artery, identification and preservation of no or only a single parathyroid gland and Graves' disease emerged as independent risk factors. In bilateral thyroid surgery, even when a standard capsular technique is adopted, results still vary, with apparently inexplicable temporary but not permanent hypocalcemia. Patients undergoing TT without neck dissection 6\% developed hypocalcemia in post-operative period however $57 \%$ of patient with TT and neck dissection developed hypocalcaemia, more importantly permanent hypocalcemia was more frequent in TT with neck dissection than in TT only ( $8.5 \%$ vs $2.8 \%)$. Occurrence of post-operative hypocalcaemia was lesser in patients undergoing TT for benign diseases in whom capsular dissection was applied and in hemithyroidectomy (33\% vs $21 \%$ respectively). In hemithyroidectomy group $(\mathrm{n}=19), 4$ patients developed hypocalcemia, all the patients except one developing hypocalcemia in hemithyroidectomy group were having serum vitamin $\mathrm{D}$ levels $<10 \mathrm{ng} / \mathrm{ml}$ with a mean value of $9 \pm 5 \mathrm{ng} / \mathrm{ml}$ and fall in post-operative serum PTH from its pre-operative level was $30 \%$. In hemithyroidectomy no dissection is done on other half, hence occurrence of hypocalcemia in hemithyroidectomy group is difficult to explain, however one plausible explanation is presence of vitamin D deficiency with severe vitamin D deficiency $(<10 \mathrm{ng} / \mathrm{ml})$ in 3 out of 4 patients developing hypocalcemia in postoperative period. In this setting pre-operative vitamin $\mathrm{D}$ deficiency appears to be the single most important factor in predicting post-operative hypocalcemia in patients undergoing hemithyroidectomy. In hemithyroidectomy even if one lobe of thyroid is removed there are chances of venous stasis due to oedema in the operative field which temporarily gives rise to a deteriorated vascular supply to the parathyroids [13]. Number of parathyroids vary from 2-6 and there is also a variation in their anatomical location [14]. Hence even if one lobe is handled chances of parathyroid injury cannot be ruled out.

In our study parathyroid auto transplantation was routinely performed whenever a parathyroid gland ischemia or injury was identified .Despite potentially excellent long-term results, the liberal resection and auto transplantation of the parathyroid glands carries a high risk of temporary but clinically significant hypocalcemia [1]. Thomusch et al emphasized that at least 2 parathyroid glands should be identified and preserved to prevent hypoparathyroidism and they found that no additional benefit was evident by having more than two identified and preserved parathyroid glands [5]. The safety of parathyroid auto transplantation is not absolute. Even after auto transplantation of parathyroid glands the graft is not completely revascularized before 3 weeks [15]. Hence patient may develop hypocalcemia in immediate post-operative period even if parathyroid glands are auto-transplanted which disappears later usually after 68 weeks. One cannot exclude the progressively increased function of a supernumerary, rudimentary fifth parathyroid gland at a thymic or mediastinal site. In our study $[\mathrm{n}=35] 7$ patients $(20 \%)$ received parathyroid gland auto transplantation in their ipsilateral sternocleidomastoid muscle, two parathyroid glands were identified and implanted in 5 patients whereas in the remaining two patients only one parathyroid gland was implanted. Out of 7 patients who received parathyroid auto transplantation, 4(57\%) had post-operative hypocalcaemia and 1 (14.3\%) had evidence of hypocalcemia at 3 months.

Hence in our study, although parathyroid auto transplantation had no significant impact on early postoperative hypocalcaemia it has got a significant effect when permanent hypoparathyroidism is considered.

Hemodilution is one factor which may be responsible for changes in serum calcium levels in perioperative period and it also explains their occurrence with other extra cervical operations of the same magnitude and duration as with thyroidectomy [9].

In patients with hyperthyroidism, when normal parathyroid function can be documented, "hungry bone syndrome" appears to be the most probable cause of hypocalcaemia in hyperthyroid patients. The risk of hypocalcaemia is not alleviated by the correction of hyperthyroidism within a few weeks before thyroidectomy. It is correlated with the pretreatment serum levels of free thyroxine and with markers of bone turnover rate, such as serum alkaline phosphatase levels and urinary hydroxyproline levels $[8,9]$.

\section{Vitamin D deficiency and it's correlation with the occurrence of post-operative hypocalcaemia}

It is now recognized and documented that vitamin $\mathrm{D}$ deficiency is one of the most common medical condition in the world [15]. Western data shows a prevalence of $30-50 \%$ in both children and adults $[16,17]$. Contrary to popular belief that India being a tropical country must have a low prevalence of vitamin D deficiency, several Indian studies have now shown a high prevalence of vitamin D deficiency [18-20]. Vitamin D has a critical role in calcium homeostasis. Like other hormones, 1, 25 $(\mathrm{OH})_{2}$ D (vitamin D3) circulates at picogram concentrations that are 1000 times less than those of the precursor $25(\mathrm{OH}) \mathrm{D}$. Based on the need for increased $\mathrm{ca}^{2+}$ absorption, the synthesis of $1,25(\mathrm{OH})_{2} \mathrm{D}$ is tightly regulated and stimulated primarily by serum parathyroid hormone $(\mathrm{PTH})$, as well as low serum calcium or phosphorus 
levels, and inhibited by circulating FGF23 produced by osteocytes. Although produced in the kidney, $1,25(\mathrm{OH})_{2} \mathrm{D}$ acts at a distance in the intestinal cell to increase $\mathrm{ca}^{2+}$ absorption or in the bone to stimulate differentiation and activation of osteoblasts and osteoclasts [21]. Insufficient $\mathrm{Ca}^{2+}$ absorption due to low vitamin D concentrations leads to an increase in PTH secretion. Increased PTH stimulates the synthesis of calcitriol and thereby improves $\mathrm{Ca}^{2+}$ absorption efficiency $[22,23]$. We hypothesized that patients with preoperative normal serum vitamin D levels can compensate for postoperative hypocalcemia due to parathyroid injury without clinical and laboratory indications of hypocalcemia. High frequency of vitamin D deficiency could be responsible for the relatively high frequency of temporary postoperative hypocalcemia in our study. We found that low preoperative serum vitamin D were significantly associated with postoperative hypocalcemia. In our study out of 24 patients with serum vitamin D levels $<20 \mathrm{ng} / \mathrm{ml} 11(46 \%)$ developed post-operative hypocalcemia, it's worth noting here that overall 12 patients developed post-operative hypocalcemia in the patients under study $(\mathrm{n}=35)$, and 11 (90\%) of them were vitamin D deficient. In patients with serum vitamin D levels $\geq 20 \mathrm{ng} / \mathrm{ml}$ only one patient developed post-operative hypocalcemia who had bilateral surgery in the form of TT. These observations suggest a crucial role of vitamin D deficiency in post-operative hypocalcemia after thyroid surgery.

As already discussed serum calcium levels are regulated by multiple factors, parathormone and vitamin $\mathrm{D}$ levels being two most important factors. In patients with parathyroid ischemia or injury, any kind of fall in postoperative serum $\mathrm{ca}^{2+}$ levels is unable to increase the secretion of PTH from ischemic/injured parathyroid glands, hence their dependence on serum vitamin $\mathrm{D}$ to maintain adequate serum $\mathrm{ca}^{2+}$ levels increase. Vitamin D acts on enterocytes to increase absorption of $\mathrm{ca}^{2+}$ from intestine. In vitamin $\mathrm{D}$ deficient patients this mechanism of increased $\mathrm{ca}^{2+}$ absorption is impaired hence these patients fail to maintain their serum $\mathrm{ca}^{2+}$ levels in the setting of impaired parathyroid functioning and develop hypocalcemia either biochemical or symptomatic. Similar studies investigating role of serum vitamin D in the occurrence of post-operative hypocalcemia after thyroidectomy has shown concordant results with our study $[21,24,25]$.

\section{Conclusion and recommendation}

Pre-operative serum vitamin D levels have got positive correlation with serum calcium levels in early post-operative period. Patients with serum vitamin D levels $<20 \mathrm{ng} / \mathrm{ml}$ are highly likely to develop early post-operative hypocalcemia and the difference between pre-operative and postoperative serum calcium levels in vitamin $\mathrm{D}$ deficient patients was significant $(\mathrm{p}<0.001)$. Occurrence of postoperative symptomatic hypocalcemia is more common in patients with vitamin $\mathrm{D}$ deficiency. In our study preoperative vitamin $\mathrm{D}$ deficiency appears to be the single most important factor in predicting post-operative hypocalcemia in patients undergoing unilateral surgery (hemithyroidectomy) in whom parathyroid ischemia and injury is unlikely. We recommend prophylactic administration of vitamin D to prevent occurrence of hypocalcemia in early post-operative period in patients undergoing thyroid surgery.

\section{Consent}

Written informed consent was obtained from all the patients for the publication of this report and any accompanying images.

\section{Competing interests}

The authors declare that they have no competing interests.

\section{Authors' contributions}

All authors read and approved the final manuscript.

\section{Author details}

'Department of Surgical Oncology, Pt.B.D.Sharma PGIMS and UHS, Rohtak, Haryana 124001, India. ${ }^{2}$ Department of Surgery, Pt.B.D.Sharma, PGIMS and UHS, Rohtak, Haryana 124001, India.

Received: 19 September 2014 Accepted: 13 October 2014 Published: 15 December 2014

\section{References}

1. Roh $J$, Park JY, Park Cl: Prevention of postoperative hypocalcemia with routine oral calcium and vitamin D supplements in patients with differentiated papillary thyroid carcinoma undergoing total thyroidectomy plus central neck dissection. Cancer 2009, 115(2):251-258.

2. Pappalardo G, Guadalaxara A, Frattaroli FM, Illomei G, Falaschi P: Total compared with subtotal thyroidectomy in benign nodular disease: personal series and review of published reports. Eur J Surg 1998, 164(7):501-506.

3. Pattou F, Combemale F, Fabre S, Carnaille B, Decoulx M, Wemeau L: Hypocalcemia following thyroid surgery: incidence and prediction of outcome. World J Surg 1998, 22(7):718-724.

4. Demeester-Mirkine N, Hooghe L, Van Geertruyden J, DeMaertelaer V: Hypocalcemia after thyroidectomy. Arch Surg 1992, 127:854-858

5. Thomusch O, Machens A, Sekulla C, Ukkat J, Lippert H, Gastinger I: Multivariate analysis of risk factors for postoperative complications in benign goiter surgery: prospective multicenter study in Germany. World J Surg 2000, 24(11):1335-1341.

6. Erbil Y, Barbaros U, Temel B, Turkoglu U, Işsever H, Bozbora A, Ozarmağan S, Tezelman S: The impact of age, vitamin D3 level, and incidental parathyroidectomy on postoperative hypocalcemia after total or near total thyroidectomy. Am J Surg 2009, 197(4):439-46.

7. Yamashita H, Noguchi S, Murakami T, Uchino S, Watanabe S, Ohshima A: Predictive risk factors for postoperative tetany in female patients with Graves'disease. J Am Coll Surg 2001, 192(4):465-468.

8. Bellantone R, Lombardi CP, Raffaelli M, Boscherini M, Alesina PF, De Crea C, Traini $E$, Princi $P$ : Is routine supplementation therapy (calcium and vitamin D) useful after total thyroidectomy? Surgery 2002, 132(6):1109-1112. discussion 1112-3.

9. Testa A, Fant V, De Rosa A, Fiore GF, Grieco V, Castaldi P, Persiani R, Rausei S, D'ugo D, De Rosa G: Calcitriol plus hydrochlorothiazide prevents transient post-thyroidectomy hypocalcemia. Horm Metab Res 2006 38(12):821-826.

10. Diez Alonso M, Sanchez Lopez JD, Sanchez-Seco Pena MI, Ratia Jimenez T, Arribas Gomez I, Rodriguez Pascual A, Martín-Duce A, Guadalix Hidalgo G, 
Hernández Domínguez S, Granell Vicent J: Serum PTH levels as a predictive factor of hypocalcaemia after total thyroidectomy. Cir Esp 2009, 85:96-102.

11. Wingert DJ, Friesen SR, lliopoulos JI, Pierce GE, Thomas JH, Hermreck AS: Post-thyroidectomy hypocalcemia. Incidence and risk factors. Am J Surg 1986, 152(6):606-610.

12. Khafif A, Pivoarov A, Medina JE, Avergel A, Gil Z, Fliss DM: Parathyroid hormone: a sensitive predictor of hypocalcemia following total thyroidectomy. Otolaryngol Head Neck Surg 2006, 134(6):907-910.

13. Michie W, Stowers JM, Frazer SC, Gunn A: Thyroidectomy and the parathyroids. Br J Surg 1965, 52:503-513.

14. Gilmour JR: The gross anatomy of the parathyroid glands. J Path Bact 1938, 46:133-149.

15. Lombardi CP, Raffaelli M, Princi P, Santini S, Boscherini M, De Crea C, Traini E, D'Amore AM, Carrozza C, Zuppi C, Bellantone R: Early prediction of postthyroidectomy hypocalcemia by one single iPTH measurement. Surgery 2004, 136:1236-1241.

16. Holick MF: Vitamin D deficiency. N Engl J Med 2007, 357(3):266-81. doi:266.

17. Sedrani SH: Low 25 -hydroxyvitamin $D$ and normal serum calcium concentrations in Saudi Arabia: Riyadh region. Ann Nutr Metab 1984, 28:181-185.

18. Marwaha RK, Tandon N, Reddy DR, Aggarwal R, Singh R, Sawhney RC, Saluja $B$, Ganie MA, Singh S: Vitamin D and bone mineral density status of healthy schoolchildren in northern India. Am J Clin Nutr 2005, 82:477-482.

19. Vupputuri MR, Goswami R, Gupta N, Ray D, Tandon N, Kumar N: Prevalence and functional significance of 25-hydroxyvitamin $D$ deficiency and vitamin $\mathrm{D}$ receptor gene polymorphisms in Asian Indians. Am J Clin Nutr 2006, 83(6):1411-1419.

20. Zargar AH, Ahmad S, Masoodi SR, Wani Al, Bashir MI, Laway BA, Shah ZA: Vitamin D status in apparently healthy adults in Kashmir Valley of Indian subcontinent. Postgrad Med J 2007, 83:713-716.

21. Arya V, Bhambri R, Godbole MM, Mithal A: Vitamin D status and its relationship with bone mineral density in healthy Asian Indians. Osteoporos Int 2004, 15:56-61.

22. Weaver S, Doherty DB, Jimenez C, Perrier ND: Peer-reviewed, evidence-based analysis of vitamin $D$ and primary hyperparathyroidism. World J Surg 2009, 33(11):2292-2302.

23. Holick MF, MacLaughlin JA, Clark MB, Holick SA, Potts JT Jr, Anderson RR, Blank IH, Parrish JA, Elias P: Photosynthesis of pre vitamin D3 in human skin and the physiologic consequences. Science 1980, 210:203-205.

24. Toniato A, Boschin IM, Piotto A, Pelizzo M, Sartori P: Thyroidectomy and parathyroid hormone: tracing hypocalcemia-prone patients. Am J Surg 2008, 196(2):285-288.

25. Cayo AK, Yen TW, Misustin SM, Wall K, Wilson SD, Evans DB, Wang TS: Predicting the need for calcium and calcitriol supplementation after total thyroidectomy: results of a prospective, randomized study. Surgery 2012, 152(6):1059-1067.

doi:10.1186/1756-6614-7-8

Cite this article as: Tripathi et al: Effect of preoperative vitamin D deficiency on postoperative hypocalcemia after thyroid surgery. Thyroid Research 2014 7:8.

\section{Submit your next manuscript to BioMed Central and take full advantage of:}

- Convenient online submission

- Thorough peer review

- No space constraints or color figure charges

- Immediate publication on acceptance

- Inclusion in PubMed, CAS, Scopus and Google Scholar

- Research which is freely available for redistribution 